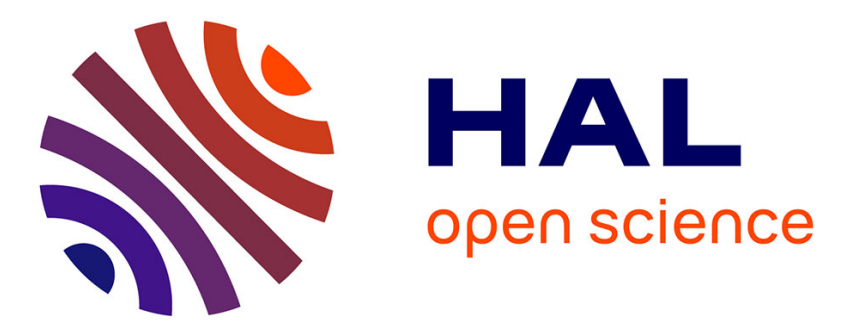

\title{
The Geography of the Holocaust in Italy: Spatiotemporal Patterns of Arrests for Families and Individuals and a Conceptual Model
}

Maël Le Noc, Alberto Giordano, Tim Cole

\section{- To cite this version:}

Maël Le Noc, Alberto Giordano, Tim Cole. The Geography of the Holocaust in Italy: Spatiotemporal Patterns of Arrests for Families and Individuals and a Conceptual Model. Professional Geographer, 2020, 72 (4), pp.575-585. 10.1080/00330124.2020.1758572 . hal-02875065

\section{HAL Id: hal-02875065 \\ https://hal.science/hal-02875065}

Submitted on 4 Oct 2020

HAL is a multi-disciplinary open access archive for the deposit and dissemination of scientific research documents, whether they are published or not. The documents may come from teaching and research institutions in France or abroad, or from public or private research centers.
L'archive ouverte pluridisciplinaire HAL, est destinée au dépôt et à la diffusion de documents scientifiques de niveau recherche, publiés ou non, émanant des établissements d'enseignement et de recherche français ou étrangers, des laboratoires publics ou privés. 
The Geography of the Holocaust in Italy:

Spatio-Temporal Patterns of Arrests for Families and Individuals and a Conceptual Model

by

Maël Le Noc, Texas State University

Alberto Giordano, Texas State University

Tim Cole, University of Bristol

The version of record of this manuscript has been published and is available in The Professional

Geographer, June 2020. http://tandfonline.com/10.1080/00330124.2020.1758572

Do not cite, quote, or reprint this postprint without permission.

Instead, cite: Le Noc, M. A. Giordano and T. Cole. 2020. The Geography of the Holocaust in Italy: Spatio-Temporal Patterns of Arrests for Families and Individuals and a Conceptual Model.

The Professional Geographer. https://doi.org/10.1080/00330124.2020.1758572 


\begin{abstract}
Holocaust and genocide scholars have long recognized the family as a relevant, if neglected, topic of research. In this article, we examine the spatio-temporal patterns of Jewish arrests during the Holocaust in Italy, concentrating on family patterns and building on previous work on arrest patterns for individuals. Starting from a large historical GIS of individual victims, we devised a methodology to identify family groups and determine if and when family members were arrested together, thereby achieving the objective of studying the event from multiple resolutions and scales of analysis. Results show considerable differences in spatio-temporal patterns for families and individuals, suggesting a higher vulnerability of families to round-ups and marked differences as concerns the nationality of both perpetrators and victims. In addition to contributing to the geography of the Holocaust, the conceptual model we devised for this study can be used in other contexts where the family is the object of research.
\end{abstract}

Keywords: Holocaust geography, Italy, spatiotemporal patterns of arrest, families and individuals. 


\section{Introduction}

Geographical scholarship on the Holocaust has come a long way since Andrew Charlesworth (1992) lamented a lack of interest in the topic among geographers. The Holocaust was indeed a profoundly spatial event, both as it was implemented by the perpetrators and as it was experienced by the victims (Cole 2003, 2016; Charlesworth 2004; Gigliotti 2009; Knowles, Cole, and Giordano 2014). Scholars have highlighted the centrality of spatial concepts such as lebensraum (literally "living space”) to Nazi ideology and policy (Bassin 1987; Rösslør 1989; Clarke, Doel, and McDonough 1996; Barnes and Minca 2013; Barnes 2015; Giaccaria and Minca 2016), as well as mapped out the ways that new spaces and places (e.g. ghettos, camps) were created across occupied Europe (Cole and Smith 1995; Cole 2003; Knowles, Cole, and Giordano 2014). In this article, we build on previous work (Giordano and Holian 2014) to examine the spatio-temporal patterns of arrests of individuals and families during the Holocaust in Italy.

Until the mid- to late-1930s antisemitism had little political and social impact in the life of Italian Jews. Starting in 1936, this changed due to a variety of factors, the most important of which was the desire by the Fascist regime to align Italy's domestic policies with those of Germany, which had become a closer ally due to Italy's increasing international isolation in the aftermath of the conquest of Ethiopia (on this issue, see De Felice 1972). In November 1938, the Italian government enacted a series of racial laws directed at the country's Jewish population, including a ban on "interracial" marriages, the prohibition for Jewish children to attend public schools, and a ban on public sector employment. These laws were preceded in August 1938 by a racial census, which recorded a total of about 58,400 people of Jewish descent living in Italy, including about 10,400 foreigners - a tiny proportion of the total country population of 
approximately 42.4 million in 1936. The numbers for those who declared themselves Jewish by religion were even lower-about 46,600 in total, including 9,400 foreigners. Most Jews lived in the northern and central parts of the country, especially in Rome, Venice, Trieste, Florence, Ferrara, and Turin. Primarily urban, the Italian Jewish population was traditionally secular and intermarriage was common: by the time of the 1938 racial census, one in three Jews married an individual of another religion (Sarfatti 2006, 27). Foreign-born Jews who had fled Germany and German-occupied territories were singled-out for additional persecutory measures, including in September 1938 the expulsion of Jews who had immigrated to Italy after 1919, followed in June 1940 by the internment of foreign and stateless Jews in camps especially set up for this purpose (on the internment of foreign Jews, see Voigt 1989).

As harsh as these measures were, Jews in Italy remained for the most part safe from deportation and murder until a series of events that occurred in the second half of 1943. On September 8 , shortly after the deposition of Mussolini in July, the new government headed by Marshal Pietro Badoglio signed an armistice with the Allies, who were quickly moving north along the Italian peninsula after the occupation of Sicily and the south. In response to the agreement, German forces occupied the northern half of the country and reinstalled Mussolini as the head of a new Fascist government, the Italian Social Republic (Repubblica Sociale Italiana, or RSI), a puppet regime with the real power laying in the hand of the Germans. These events signaled the beginning of the "hunt for Jews" (caccia all'ebreo) in Italy. Northern and central Italy were divided into two main areas, with two "operation zones"- the Operationszone Alpenvorland and the Operationszone Adriatisches Küstenland, both in the northeast—directly controlled by the Germans, with the remaining territory—-the RSI—under nominal Italian control. In the RSI, Italian involvement in the hunt for Jews was extensive and systematic, with 
the new Fascist government articulating its own antisemitic policies, including, on November 30, a decree ordering the arrest, confinement, and confiscation of the properties of all Jews residing in Italy. For the first time, the distinction between Italian and foreign Jews, heretofore central to Fascist policy, was erased, and all Jews were now subject to arrest and internment and vulnerable to deportation.

Germans took the lead in carrying out the arrest of Jews during the early stages of the Holocaust in Italy, mostly through the execution of large-scale round ups in cities with large Jewish populations, such as the raid in Rome on 16 October 1943 during which 1,259 Jews were arrested. After those first mass arrests by the Germans, Italian police forces were put in charge of arresting Jews in the RSI. Over the next year and a half, Italian perpetrators systematically and extensively combed the countryside, searching for and arresting Jews in hiding or trying to flee. In the end, between September 1943 and March 1945, some 10,000 Jews were deported from Italy to Nazi concentration and extermination camps, with a vast majority being murdered, principally in Auschwitz. Jewish victims were arrested for the most part in their place of last residence, although approximately a third were captured in other cities or towns while trying to flee persecution. Arrests were proportional to the 1938 Jewish population in Rome, Florence, and all of northeastern Italy, but relatively less than expected in Milan, Livorno, and Turin. A number of important outliers emerge, most notably the Swiss border and Borgo San Dalmazzo (see below and Giordano and Holian 2014 for an in-depth discussion). Estimates indicate that around 500 Jews were able to escape to the south of Italy, with a further 5,000 to 6,000 escaping to Switzerland (Zuccotti 1987; Sarfatti 2005). While the numbers of the Holocaust in Italy are small when compared to other countries under Nazi rule, for the country's small Jewish population these losses were staggering. 


\section{On families, geography, and the Holocaust}

As we argue in this article, there is value in studying the Holocaust in Italy not only through the lens of the individual or the community, as we have done elsewhere (Giordano and Holian 2014), but also looking at the family, as the family in general is an important but somewhat neglected topic of research in both geography and Holocaust Studies. As concerns geography, a decade ago Valentine $(2008,2098)$ identified the 'family' as an "absent presence" within the discipline, although in recent years the idea of "family geographies" as a distinct subdiscipline has begun to emerge (Tarrant and Hall 2019)Harker and Martin 2012; Pimlott-Wilson and Hall 2017; Tarrant and Hall 2019). Despite these efforts, the need for a geographical theorization of the family prevails and Valentine's $(2008,2017)$ call to "refine the methodological tools" used to study the family remains relevant today. For their part, Holocaust scholars have tended to consider victims as either individuals or en masse (the six million), despite the fact that, as von Joeden-Forgey $(2010,1)$ notes, "genocide $[\ldots]$ is a crime that is inextricably tied to families," as was the case with the racial laws enacted in 1938 in Italy. The family is targeted by perpetrators as the place of reproduction of human life and the place of cultural reproduction through education, and also for practical reasons, as members of the targeted group can be found in households. The topic of the family, in particular when dealing with the trauma of family separations, is recurrent in Holocaust narratives and testimonies (Chaitin and Bar-On 2002; von Joeden-Forgey 2010; Cole 2015), as the two following examples from Italy demonstrate. Piero Terracina and his family managed to escape the raid of the Rome Ghetto on 16 October 1943 and went into hiding until 7 April 1944, when they were betrayed by an informer and captured in Rome. The entire family, including Piero's parents, Lidia and 
Giovanni, his siblings, Leo, Cesare and Anna, one uncle, Amedeo, and his grandfather, Leone, were deported to Auschwitz. Piero was the only one to survive (Terracina 1998). Gilberto Salmoni's story was quite different. A native of Genoa, Gilberto was arrested by Italian police in April 1944 with his mother and father, Vittorina and Gino, his brother, Renato, and his sister, Dora, while the family was attempting to escape to neutral Switzerland. Deported to Buchenwald in August 1944 with his brother, Gilberto survived the Holocaust and returned to Genoa, where he still lives, while his parents and sister were sent to Auschwitz and killed upon arrival or immediately thereafter (Salmoni 1998, 2005, 2013, 2016).

In spite of the poignancy and relevance of family narratives in the experience of the survivors, there has been relatively little research on families in Holocaust Studies, as pointed out by Pine (2004). When families are the object of research, the focus is typically on issues related to gender and gender roles (Baumel 1996; Pine 2004), or on the experiences of women and children (Wardi 1992; Ofer and Weitzman 1999; Hertzog 2008; Heberer 2011), although a handful of scholars have extended their gaze beyond these topics, including Pine's (2000) and Kaplan's $(1998,2005)$ works on Jewish families in Nazi Germany between 1933 and 1939; Ofer (1999), Iskov (2011), and Weitzman's (2017) examination of family structures, strategies, and roles in East European ghettos; and Chaitin and Bar-On's (2002) research on survivors' memories of family relationships. Regardless of focus, this literature is characterized by the employment of qualitative methods. Most similar to our work with quantitative spatial analytical techniques is Mariot and Zalc's $(2010,2017)$ prosopographical study of the persecution of the Jews of Lens in France, in which the authors use statistical analysis to study individuals and families separately, including their spatial trajectories and ultimate fate. 
Finally, the family is a basic unit of study in many social science disciplines.

Sociologists, for example, have studied its structure, differentiating between nuclear and extended family, as well as proposing non-structural approaches, for instance focusing on family members living in the same household or on family roles (Ciabattari 2016). Johnson $(2000,625)$ defines the nuclear family as composed of a married couple and their dependent children, with the extended family made up of individuals related by four potential types of relationships:

“(1) Lineal relationships formed by intergenerational linkages; (2) collateral relationships linked through siblings and other kin of similar age status; (3) in-law relationships created through marriage; and (4) fictive kin created out of nonkin relationships, such as play children, Godchildren, or foster children."

For the purpose of this study, we define the family as a single unit of analysis - regardless of its size - that includes both the nuclear and the extended family as defined by Johnson, but excludes fictive kin, as our data do not allow the identification of this type of relationship.

\section{Data and methods}

In 2002, Liliana Picciotto Fargion published a revised edition of her 1991 list of about 9,000 Jews deported from Italy during the Holocaust. The list is the backbone of the historical GIS (HGIS) of the Holocaust in Italy created by Giordano and Holian (2014), which includes the names of 6,116 victims for whom the location of arrest was known, along with information regarding the victim's birthplace and birth date, the names of the victim's mother, father, and spouse, the date of arrest, the camp of final deportation, intermediate places of detention in Italy, and the victim's fate. Not included in the HGIS are individuals for whom the place of arrest was not known, or who were not deported, or who were arrested in territories that are not part of Italy 
today (for example, the island of Rhodes in Greece). Because of its detail and comprehensiveness, the list allows the reconstruction of family groups and the comparison of the spatio-temporal patterns of individuals with those of families. To our knowledge, such a comparison has never been tried in Holocaust Studies, at least not at the scale of a country.

Starting from the name of the parents and —if applicable — the names of the spouse of the victim in the HGIS, we were able to identify family groups that included both nuclear and extended family relations. This allowed us to reconstruct each victim's family tree, in some cases across multiple generations. To do this, we designed a Python script ${ }^{1}$ that assigned a shared family ID number to any two individuals who had the same two parents, who were married to each other, or for whom one was the parent of the other. Once this was done, we assigned spatial and temporal attributes (i.e., the date and place of arrest) to the family groups identified. The process led to the identification of what we termed Arrested Family Groups (AFGs). Figure 1 illustrates the case of one family living in Rome. Some of its members were not arrested —or more precisely, not that we know of - while others were, sometime together on the same date, sometime on a different date. Thus, one single family group (in purple) can be subdivided into three subgroups (in green) based on the place and date of arrest of its individual members. These subgroups are the AFGs. Note that individuals can be members of only one extended family and only one AFG. AFGs were identified using a second, simpler, Python script that grouped individuals from the same family that were arrested together. By subdividing families in AFG, we were able to explore the spatio-temporal patterns of family arrests during the Holocaust in Italy and compare them to the patterns identified by Giordano and Holian (2014) for individual victims.

\footnotetext{
${ }^{1}$ All scripts mentioned in this article are available upon request from the authors.
} 


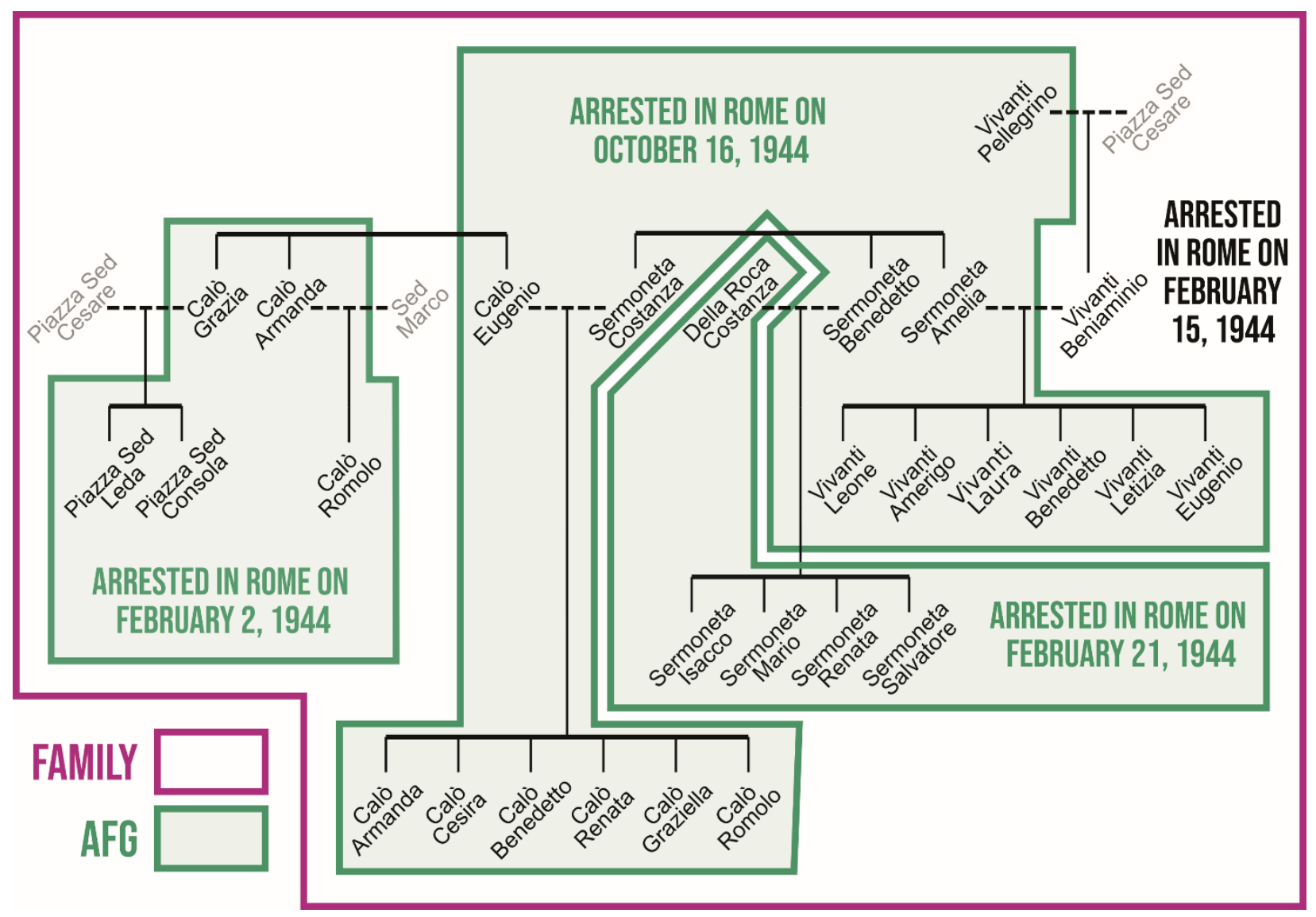

Figure 1. Example of one family and its related AFGs.

In light grey are individuals for which no entry exists in the database

\section{Discussion of results}

Using the scripts described in the preceding section, we were able to identify 1,203

extended families, with as many as 31 members (this is the family in figure 1). 4,358 of the 6,116 individuals (71.2 percent) have at least one family member who is also in the database. 56.5 percent $(3,456)$ of the victims were arrested with other members of their family, for a total of 1,062 AFGs, showing — as expected from the Holocaust and genocide literature- that perpetrators were especially efficient and effective at targeting family groups, and arrested family members together, at the same time and at the same place. The average size of an AFG is 3.25 , with a standard deviation of 2.1 , but at 18 (with 2 and 20 as minimum and maximum), the 
range of members of an AFG is large. About 15 percent of the victims had family members in the database but were not arrested with them (one such example is "Beniamino Vivanti" in figure 1). As oral histories of the Holocaust in Italy and elsewhere confirm, plausible explanations for such cases include families being separated during flight, with some members being able to stay in hiding longer than others, or families trying to flee in smaller subgroups.

The gender distribution of victims in AFGs (54 percent women) is almost identical to the gender distribution for the total number of victims (52.2 percent women). More interesting are the age differences, especially as concerns the large proportion of children—defined here as individuals 16 and younger - in AFGs (22 percent) compared to the overall population (14 percent). This is to be expected, as children are likely to live with their parents and are therefore likely to be arrested with them. The proportion of adults — defined as individuals of age 17-69is lower in the AFGs than in the overall population (69 percent vs. 75 percent) and so is the proportion of the elderly, which we defined as individuals 70 and older (7 percent vs. 9 percent). Regarding the nationality of the perpetrators (table 1), the percentage of AFGs arrested by Germans (40.1 percent) and by Italians (31.4 percent) is comparable to the value for individuals for Germans (39.4 percent) as well as for Italians (29.2 percent). (Note, however, the large proportion of "unknown" in the table.) As concerns birthplaces, the proportion of AFGs is lower than the total of the victims for both Italian-born and foreign-born Jews (56.2 percent vs. 63.8 percent and 31.6 percent and 34.6 percent respectively). This is largely due to the fact that, for AFGs, we were also able to calculate the proportion of "mixed" families; that is, of families composed of members born in Italy as well as outside of it. Such "mixed" families amount to 10.5 percent of the total, quite a substantial proportion. This might be due to a variety of causes already touched upon, ranging from the relatively cosmopolitan composition of the Italian Jewry 
when compared to other parts of the continent (especially Eastern Europe) to the recent arrivals of Jews from countries where the extermination process had been underway for years.

Table 1. Perpetrator's nationality and victim's place of birth for AFGs and individuals.

\begin{tabular}{|l|c|c|}
\hline & Aercentage (Number) & $\begin{array}{c}\text { Individual victims, } \\
\text { in AFG or not } \\
\text { Percentage (Number) }\end{array}$ \\
\hline Perpetrators' nationality & & \\
\hline - Italians & $31.4 \%(333)$ & $29.2 \%(1,786)$ \\
\hline - Germans & $40.1 \%(426)$ & $39.4 \%(2,410)$ \\
\hline - Italians with Germans & $5.3 \%(56)$ & $5.2 \%(319)$ \\
\hline - Unknown & $23.3 \%(247)$ & $26.2 \%(1,601)$ \\
\hline Total & $100 \%(1062)$ & $100 \%(6,116)$ \\
\hline & & \\
\hline Victim's place of birth & & $63.8 \%(3,902)$ \\
\hline - Italy & $56.2 \%(597)$ & $34.6 \%(2,114)$ \\
\hline - Not Italy & $31.6 \%(336)$ & - \\
\hline - Mixed (possible only for AFGs) & $10.5 \%(112)$ & $1.6 \%(100)$ \\
\hline - Unknown & $1.6 \%(17)$ & $\mathbf{1 0 0 \%}(\mathbf{6 , 1 1 6})$ \\
\hline Total & $\mathbf{1 0 0 \% ( 1 0 6 2 )}$ & \\
\hline
\end{tabular}

Although differences emerge between the family and the individual scale of analysis, these are relatively small for most of the variables examined. A geographical perspective highlights more significant differences. Figure 2 shows clusters of AFGs and allows for a comparison with spatio-temporal patterns at the individual level (Giordano and Holian 2014). The two cluster configurations differ in small but notable ways, especially in the case of the regions around Turin and Venice. For Turin, the AFG cluster is elongated, slightly smaller, and closer to Borgo San Dalmazzo, which is consistent with the relatively high proportion of victims arrested in AFGs at that location. For Venice, the shape and size of the AFG cluster are virtually identical to the cluster for individuals, but with a southward shift. The first two columns of table 
2 show the percentage of family groups arrested in each of the major Italian cities, as well as the percentage of all individual victims arrested in those cities. In both cases, the largest number of arrests occurred in Rome, followed by Trieste, Borgo San Dalmazzo, Florence and Milan. Except for Borgo San Dalmazzo-a small town where a large group of Jews coming from France were captured in a single day by Germans - these are all traditional centers of Jewish life in Italy. Notice, however, that these overall patterns may mask more nuanced situations at the local level. For instance, the number of family arrests in Rome is relatively low compared to the number of individual arrests (23.4 percent vs. 27.7 percent), while the percentage of family arrests in Borgo San Dalmazzo is higher than the percentage of individual arrests (6.6 percent vs. 5.4 percent). However, it would be wrong to conclude that Jews were overall less likely to be arrested with family members in Rome. In fact, both in Rome and Borgo San Dalmazzo, with respectively 62.2 percent and 66.6 percent of arrested individuals belonging to an AFG, more individuals were arrested with family members than the average for Italy (56.5 percent). What explains this apparent contradiction is the fact that the mean size of the AFGs varies considerably depending on location. In Rome, although relatively few AFGs (248) were arrested, the families tended to be bigger than the rest of the country (4.24 vs 3.25 AFG mean size). This means that a smaller number of large families were arrested in Rome. In contrast, in Borgo San Dalmazzo, a relatively large number of family groups were arrested (70), but these groups were quite small in size (3.11 members on average). The size difference can be at least in part explained by the fact that most Borgo San Dalmazzo families (and AFGs) are of the nuclear type, whereas in Rome many of the families (and AFGs) are of the extended type. The last column of the table allows us to easily identify the cities where a particularly high number of victims were arrested with one or more family member, with only Rome, Borgo San Dalmazzo, 
and Civitella del Tronto - a small town in the Abruzzo region that was the site of an internment camp for foreign-born Jews - having a higher proportion of victims in AFGs than the national average of 56.5 percent.

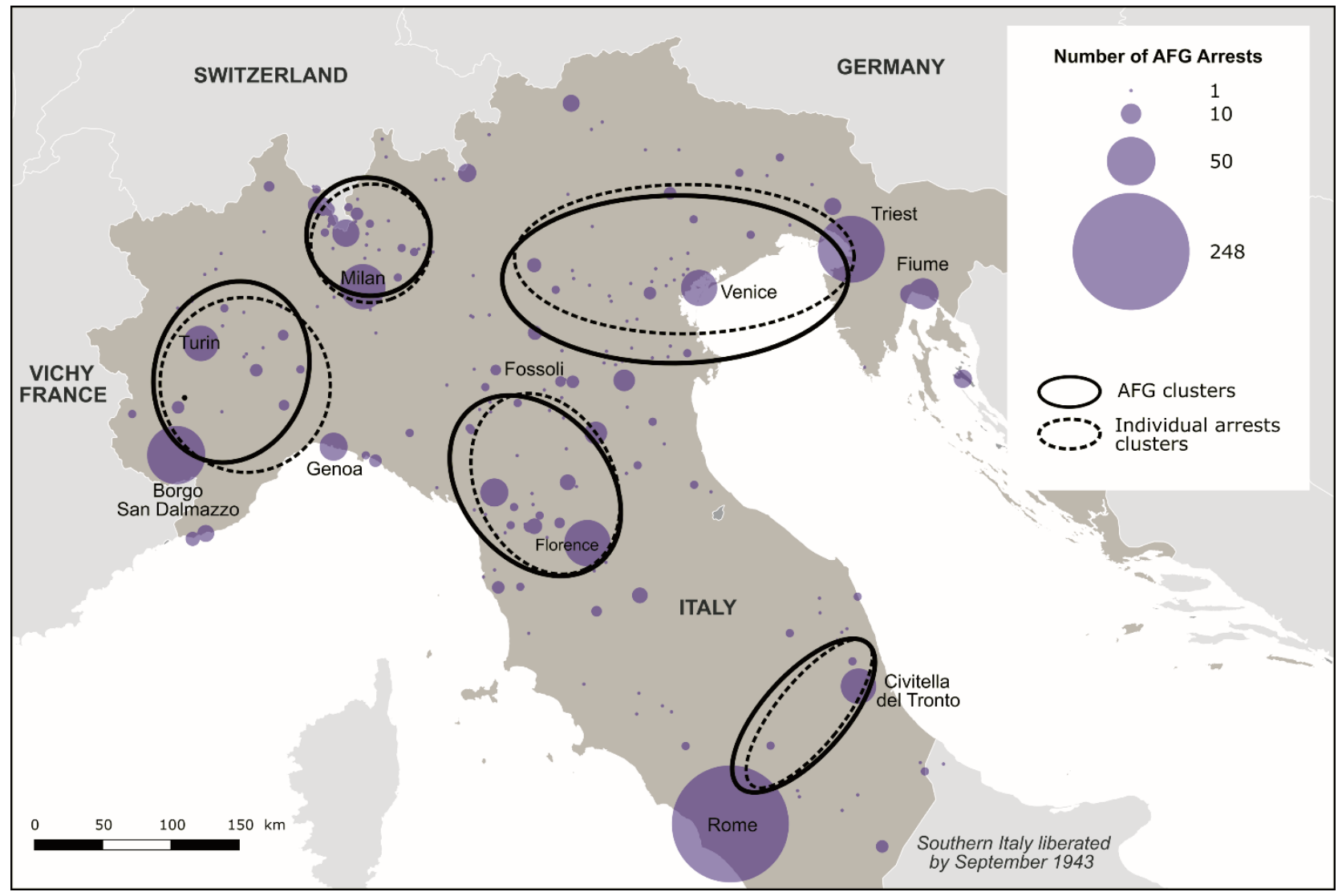

Figure 2. Comparison of AFG and individual arrest clusters. 
Table 2. Perpetrator's nationality and victim's place of birth for AFGs and individuals.

\begin{tabular}{|l|c|c|c|c|}
\hline & $\begin{array}{c}\text { AFGs } \\
\text { Percentage } \\
\text { (Number) }\end{array}$ & $\begin{array}{c}\text { Individual } \\
\text { victims, } \\
\text { in AFG or } \\
\text { not } \\
\text { Percentage } \\
\text { (Number) }\end{array}$ & $\begin{array}{c}\text { AFG } \\
\text { mean } \\
\text { size }\end{array}$ & $\begin{array}{c}\text { Percentage of individuals } \\
\text { belonging to an AFG } \\
\text { (number of individual } \\
\text { members of an AFG/total } \\
\text { number of individuals } \\
\text { arrested in the city) }\end{array}$ \\
\hline Place of Arrest & & & \\
\hline - Rome & $23.4 \%(248)$ & $27.7 \%(1,692)$ & 4.24 & $62.2 \%(1,052 / 1,692)$ \\
\hline - Trieste & $8.5 \%(90)$ & $9.0 \%(551)$ & 2.83 & $46.3 \%(255 / 551)$ \\
\hline - Borgo San Dalmazzo & $6.6 \%(70)$ & $5.4 \%(329)$ & 3.11 & $66.3 \%(218 / 329)$ \\
\hline - Florence & $4.3 \%(46)$ & $4.5 \%(274)$ & 2.91 & $48.9 \%(134 / 274)$ \\
\hline - Milan & $4.1 \%(44)$ & $4.4 \%(270)$ & 2.61 & $42.6 \%(115 / 270)$ \\
\hline - Venice & $2.7 \%(29)$ & $3.3 \%(204)$ & 3.59 & $51.0 \%(104 / 204)$ \\
\hline - Civitella del Tronto & $2.6 \%(28)$ & $2.5 \%(155)$ & 4.11 & $74.2 \%(115 / 155)$ \\
\hline - Turin & $2.6 \%(28)$ & $3.4 \%(207)$ & 2.18 & $29.5 \%(61 / 207)$ \\
\hline - Fiume & $2.1 \%(22)$ & $2.9 \%(179)$ & 3.41 & $41.9 \%(75 / 179)$ \\
\hline - Genoa & $1.7 \%(18)$ & $1.9 \%(108)$ & 2.89 & $48.1 \%(52 / 108)$ \\
\hline - Other/Unknown & $36.9 \%(439)$ & $41.3 \%(3,969)$ & 2.90 & $32.1 \%(1,273 / 3,969)$ \\
\hline Total in Italy & $\mathbf{1 0 0 \% ( 1 0 6 2 )}$ & $\mathbf{1 0 0 \% ( 6 , 1 1 6 )}$ & $\mathbf{3 . 2 5}$ & $\mathbf{5 6 . 5 \% ( 3 , 4 3 6 / 6 , 1 1 6 )}$ \\
\hline
\end{tabular}

One does not need a map to unearth and describe the geographical aspects of an event and its distribution. The Knox Index is a simple and powerful statistical tool that allows the researcher to classify a certain event - in our case, the arrest of an individual or of an AFGaccording to its temporal as well as its spatial characteristics. Events can be: a) "close" both in time and in space; b) "close" in time but not in space; c) "close" in space but not in time; d) "not close" in both time and space. For this study, consistent with what was done in Giordano and Holian (2014), we defined two places as being "close" to each other if their distance was $25 \mathrm{~km}$ or less, and we defined two events as "close" in time if they occurred in the same month. Figure 3 shows the spatio-temporal proximity of AFGs as measured by the Knox Index. Overall, almost 30 percent of all arrests (first column) occurred in spatial, temporal, or spatial and temporal closeness, with closeness in time more pronounced than closeness in space; when the nationality 
of the perpetrators was known, this value increased to over 45 percent. Arrests by Italians, as well as arrests of mixed AFGs to a lesser extent, tended to be concentrated in time but not in space, which illustrates the fact that Italian perpetrators operated extensively and with capillarity over the entirety of the study area. Conversely, Germans operated in bursts of activity that were spatially as well as temporarily concentrated or concentrated in time but not in space. Arrests of Italian-born AFGs and arrests of foreign-born AFGs follow similar patterns, with Italian-born AFGs additionally showing a robust proportion (almost 10 percent) of arrests close in space but not in time. The comparison between the AFG and the individual spatio-temporal patterns, illustrated in figure 4, shows a marked increase in arrests that are in spatial, temporal or spatial and temporal closeness relative to each other, with closeness in time higher than closeness in space, for all AFGs. With one exception - foreign-born Jewish victims - the temporal concentration of arrests is much higher when analyzed at the AFG resolution than it is when considering the overall population at the individual resolution. This confirms that perpetrators were particularly efficient at arresting multiple family groups together, not only at the national scale but also locally. This also establishes that family groups were arrested more frequently with other family groups compared to individuals being arrested with other individuals. In other words, many family groups were arrested together during bursts of activities, such as roundups, while isolated arrests of single individuals where relatively frequent. The low spatial concentration for arrests of AFGs by Italian perpetrators, already noted above, confirms that they conducted their actions over a large territory, while the high spatial and temporal concentration of arrests by German perpetrators illustrates their role in the round-ups that took place especially in Rome and also in Borgo San Dalmazzo and other places in September and October 1943. As already noted, from the point of view of the perpetrators' modus operandi, it makes sense for 
families to be arrested in higher proportions during roundups. In order to confirm that this was indeed the case, we returned to examine each individual victim, while retaining information regarding AFG membership, to compare the percentage of individuals arrested with other members of their family during round-ups in Rome, Florence, Venice and Borgo San Dalmazzo with the overall numbers for the Italian Holocaust (figure 5). As expected, the proportion of Jews that was arrested with family members during roundups in these cities was higher than the national average. This is especially true for the Rome round-up on 16 October 1943, in which more than four out of five individual victims were part of AFGs.

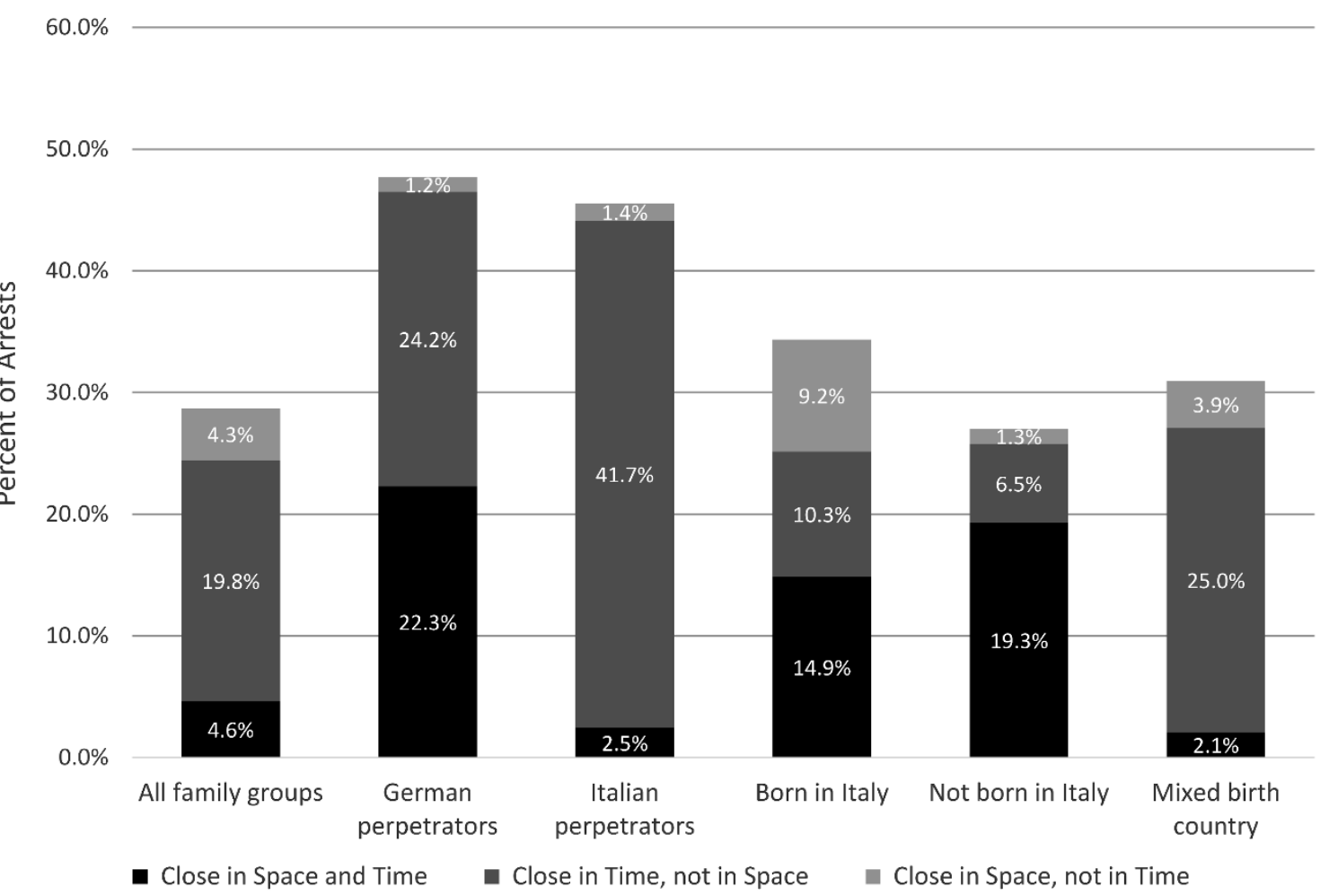

Figure 3. Spatio-temporal proximity of family arrests as measured by the Knox Index. 


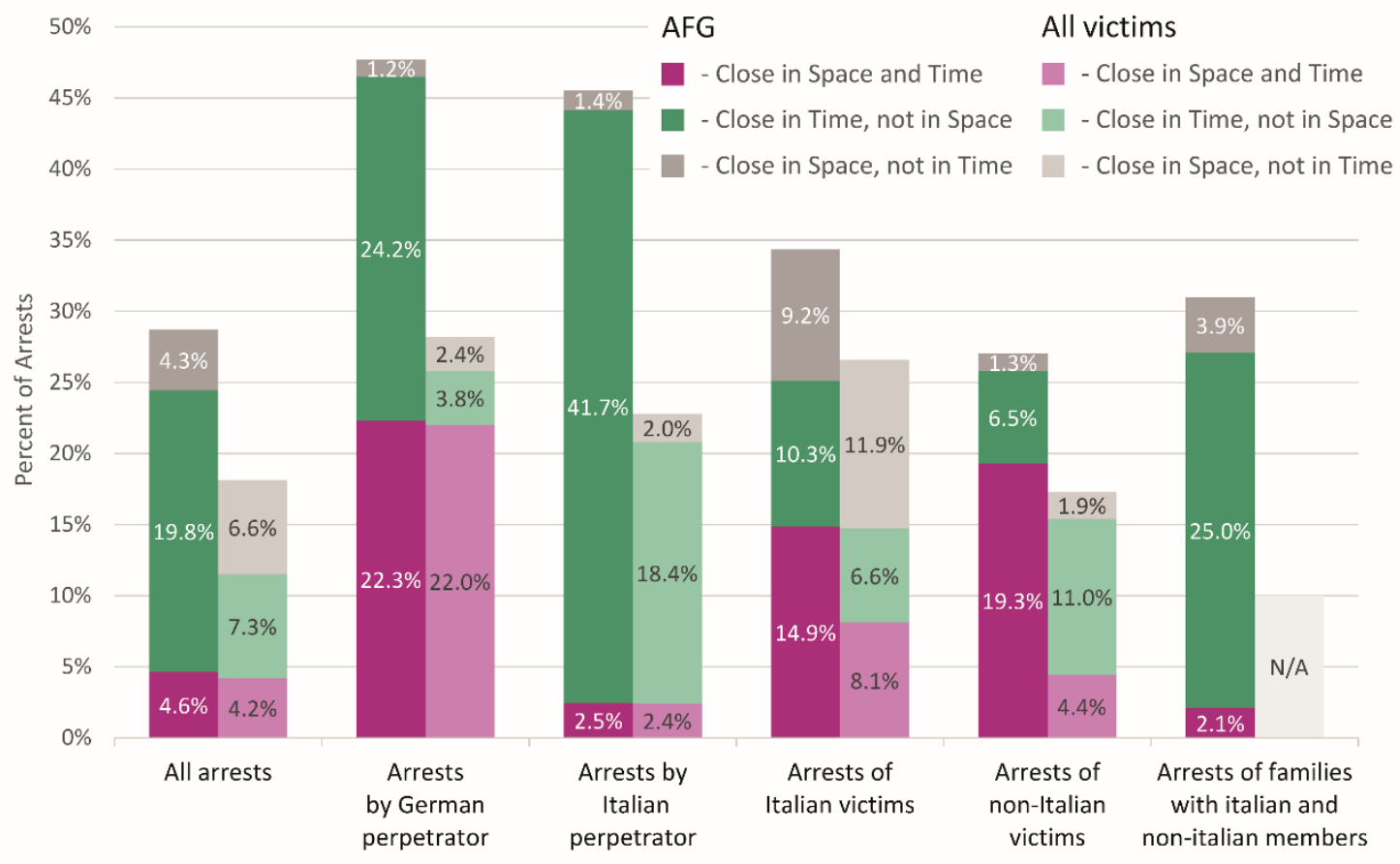

Figure 4. Comparison of spatio-temporal proximity of arrests at the resolution of the family and the individual as measured by the Knox Index.

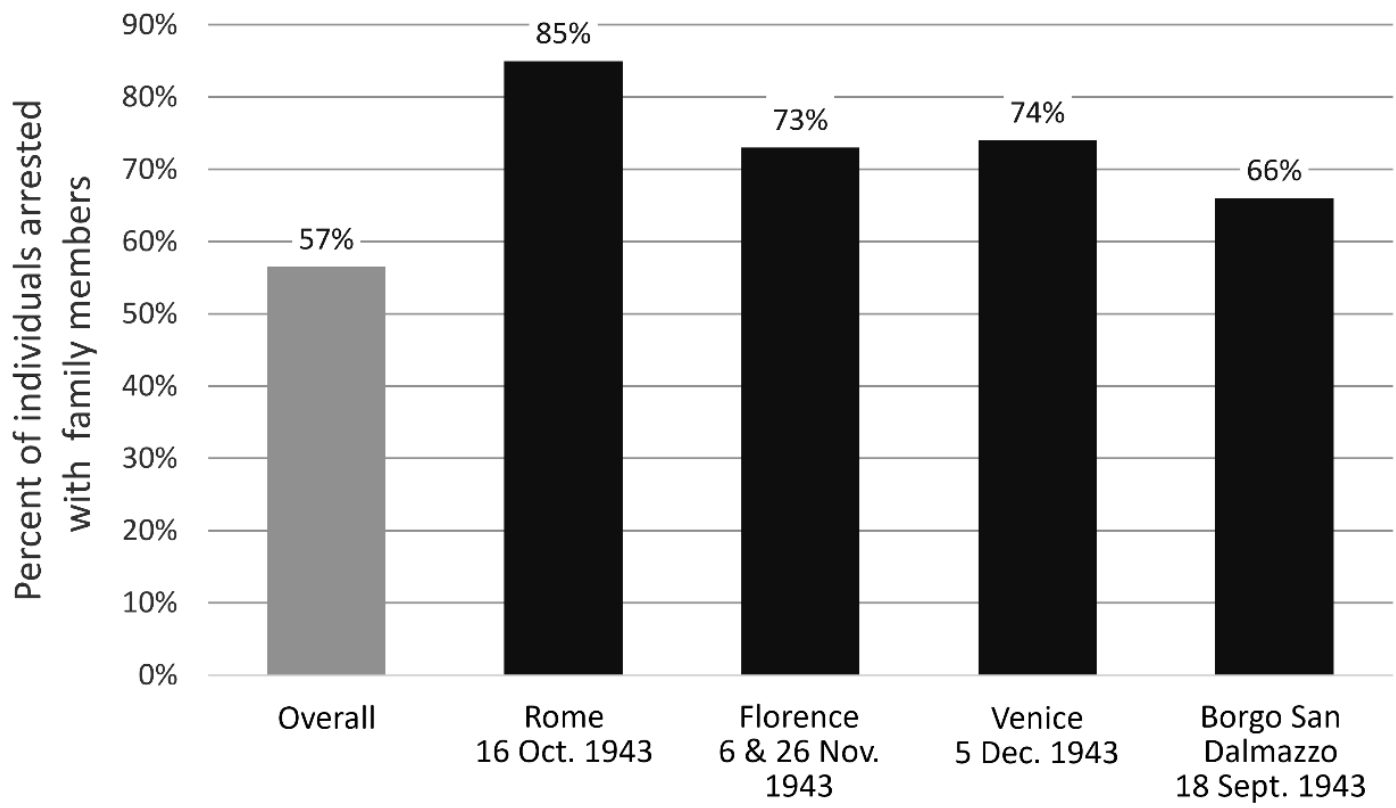

Figure 5. Proportion of individuals arrested with family members during round-ups. 
Another part of Italy with a large proportion of AFGs is the region on the border between Italy and neutral Switzerland, where many Jews tried to go to escape persecution and arrest (Broggini 1993, 1998; Bazzocco 2002). Among the 330 individuals who were caught within ten kilometers of the border, 213 (65 percent; significantly higher than the national average of 56.5 percent) were part of 77 AFGS. These victims came from all over northern and central Italy, were not from the border area, and included many foreign-born Jews, who as a rule had little or no knowledge of the region and few or no local social connections. Typically, they were small family groups of two or three members arrested at the end of a trip of several days, who had the opportunity and the means to leave home, stay in hiding (often at a price) and survive, and often hire guides to take them to Switzerland. It is a different kind of family than, for example, the victims of the round-ups in Rome, Borgo San Dalmazzo, and in other major Jewish centers, as many personal narratives clearly indicate (see, for example, Perosino 2005; Scomazzon 2005; Dalla Costa, Pignatiello, and Maistrello 2006).

\section{Conclusions}

In this article, we examine the spatio-temporal patterns of the arrest of Jews in Italy in the period between September 1943 and the early 1945. As chilling as it sounds, the spatio-temporal patterns of the Holocaust in Italy clearly show the efficiency and effectiveness of the Holocaust process as carried out by the German and Italian perpetrators. As Figures 2 through 5 reveal, both in the case of individuals and family groups, the perpetrators first targeted the traditional centers of Jewish life in Italy_-starting with Rome-where victims were rounded up in raids and found for the most part at their homes. Germans were primarily responsible for this stage, which accounted for the largest number of victims. The perpetrators then proceeded to extend their 
range of action to all of northern Italy and it is in this second stage that Italian perpetrators became particularly active. During this stage, many of the victims were caught while fleeing their home or while in hiding. The stories of Piero Terracina and Gilberto Salmoni, presented earlier in the paper, exemplify the two stages. What these two moment had in common was the sequencing of events, intended in both space and time: arrest was followed by internment, of a few days or weeks, in Italy_ - in special camps, such as Fossoli, or in regular jails or prisons—and then by deportation to camps outside of Italy. As for the division of labor, Italians and Germans were both responsible for arrest and internment, but it was the Germans who decided when the victims were to be deported to camps outside of Italy and who organized transport.

Our study also shows that the spatio-temporal patterns of the arrests of family groups (AFGs) during the Holocaust in Italy differ to some extent from the patterns for individual victims. Families are explicitly targeted by the perpetrators of genocide: one only has to be reminded of the 1935 Nuremberg Laws promulgated in Nazi Germany and their excruciatingly detailed family trees, to grasp this reality. In Italy, more than half of the Jewish victims were arrested with other members of their family, with a disproportionate number of families arrested in round-ups, to which families were especially vulnerable. Studying individuals and families simultaneously — and comparing their patterns of persecution and destruction — is especially important, as the organizational complexity, long duration, and continental scale of the Holocaust calls for an examination of the event not only at multiple spatio-temporal resolutions — as done in Knowles, Cole and Giordano (2014)_but also at multiple thematic resolutions. In the case examined in this article, Picciotto Fargion collected information on the victims at one spatial resolution, one thematic resolution, and one temporal resolution; these were, respectively, the town or city where the arrest occurred, the individual victim, and the date 
of the arrest. (Note that, in reality, in several instances the exact circumstances of the arrestespecially the exact date — could not be determined.) This dataset became the base for the construction of a HGIS which allowed us to study the Holocaust in Italy at three fundamental spatial scales - the national the local, and, with cluster analysis, also the regional—and two temporal scales - the period September 1943 to early 1945, and the month. As for the thematic dimension, the HGIS allowed us to shift resolution from the collective- "all known Jewish victims"- to the individual, and then to the family. In doing so, we proceeded to aggregate individual data twice (individual to the family and individual to the collective). If one takes into consideration all possible alternatives, the number of combinations of spatial-temporal-thematic attributes balloon very quickly to unmanageable sizes (eighteen in the case above). A choice is needed, then, and it only makes sense that the "correct" combination is achieved as the result of a process of collaboration between geographers and historians, as is the case in spatial humanities projects that employ a mixed methods research framework and are conceived and conducted from the start in a multidisciplinary fashion. For the study of the Holocaust and genocide, it is useful to look at both the individual and the family, exactly because the perpetrators explicitly target families as well as individuals. In Italy, for example, family groups were targeted during roundups and families were brought together in internment camps before being deported: the "preferred" resolution of this part of the genocidal process appear to have been the family, although exceptions occurred. Once at the camp of destination, resolution shifted back to the individual, in the sense that gendered selections conducted on arrival (for example, at Auschwitz) were based on the perceived usefulness of individual victims for slave labor, regardless of who the other members of his or her family were. That is why the demographics of the typical camp survivor is so narrow, with very few children or old people. As this discussion 
shows, at least in the case of a dynamic, complex, spatially diffused, and long process like the Holocaust, there is a need to study the event at a variety of resolutions. 


\section{References}

Barnes, T. J. 2015. “Desk killers”: Walter Christaller, central place theory, and the Nazis. In Geographies of Knowledge and Power, eds. P. Meusburger, D. Gregory, and L. Suarsana, 187201. Dordrecht, the Netherlands: Springer Netherlands.

Barnes, T. J., and C. Minca. 2013. Nazi spatial theory: The dark geographies of Carl Schmitt and Walter Christaller. Annals of the Association of American Geographers 103 (3):669-687.

Bassin, M. 1987. Race contra space: The conflict between German geopolitik and national socialism. Political Geography Quarterly 6 (2):115-134.

Baumel, J. T. 1996. Gender and family studies of the Holocaust: A historiographical overview. Women: A Cultural Review 7 (2):114-124.

Bazzocco, A. 2002. Fughe, traffici, intrighi: Alla frontiera italo-elvetica dopo l'armistizio dell' 8 settembre 1943 (Escapes, trafficking, intrigues: At the Italian-Swiss border after the armistice of 8 September 1943). Schweizerische Zeitschrift für Geschichte 52 (2):194-212.

Broggini, R. 1993. Terra d'asilo: I rifugiati Italiani in Svizzera, 1943-1945 (Land of asylum: Italian refugees in Switzerland, 1943-1945). Bologna, Italy: Il mulino.

1998. La frontiera della speranza: Gli ebrei dall'Italia verso la Svizzera, 1943-1945 (The borer of hope: Jews from Italy to Switzerland, 1943-1945. Milan, Italy: Mondadori.

Chaitin, J., and D. Bar-On. 2002. Emotional memories of family relationships during the Holocaust. Journal of Loss and Trauma 7 (4):299-326. 
Charlesworth, A. 1992. Towards a geography of the Shoah. Journal of Historical Geography 18 (4):464-469.

- 2004. The topography of genocide. In The historiography of the Holocaust, ed. D. Stone, 216-252. London, United Kingdom: Palgrave Macmillan.

Ciabattari, T. 2016. Sociology of families: Change, continuity, and diversity. Thousand Oaks, CA: SAGE Publications.

Clarke, D. B., M. A. Doel, and F. X. McDonough. 1996. Holocaust topologies: Singularity, politics, space. Political Geography 15 (6-7):457-489.

Cole, T. 2003. Holocaust city: The making of a Jewish ghetto. New York, NY: Routledge.

. 2015. (Re)placing the past: Spatial strategies of retelling difficult stories. Oral History Review 42 (1):30-49.

- 2016. Holocaust landscapes. London, United Kingdom: Bloomsbury.

Cole, T., and G. Smith. 1995. Ghettoization and the Holocaust: Budapest 1944. Journal of Historical Geography 21 (3):300-316.

Dalla Costa, I., R. Pignatiello, and F. Maistrello. 2006. La persecuzione degli ebrei in provincia di Treviso, 1938-1945 (Persecution of the Jews in the province of Treviso, 1938-1945. Treviso, Italy: Istituto per la Storia della Resistenza e della Società Contemporanea della Marca Trevigiana (Institute for the History of the Resistance and of the Contemporary Society of the Marca Trevigiana). 
De Felice, R. 1972. Storia degli ebrei italiani sotto il fascismo (History of Italian Jews under fascism). Turin, Italy: Einaudi.

Giaccaria, P., and C. Minca eds. 2016. Hitler's geographies: The spatialities of the Third Reich. Chicago, IL: The University of Chicago Press.

Gigliotti, S. 2009. The Train Journey: Transit, Captivity, and Witnessing in the Holocaust. New York, NY: Berghahn Books.

Giordano, A., and A. Holian. 2014. Retracing the "Hunt for Jews": A spatio-temporal analysis of arrests during the Holocaust in Italy. In Geographies of the Holocaust, eds. A. Knowles, T. Cole, and A. Giordano, 52-86. Bloomington, IN: Indiana University Press.

Harker, C., and L. L. Martin. 2012. Familial relations: Spaces, subjects, and politics. Environment and Planning A: Economy and Space 44 (4):768-775.

Heberer, P. 2011. Children during the Holocaust. Lanham, MD: AltaMira Press.

Hertzog, E. 2008. Life, death and sacrifice: Women and family in the Holocaust. Jerusalem, Israel: Gefen Books.

Iskov, R. 2011. Familial resistance in the Łódź ghetto. PRISM: An Interdisciplinary Journal for Holocaust Educators 3:20-26.

von Joeden-Forgey, E. 2010. The devil in the details: "Life force atrocities" and the assault on the family in times of conflict. Genocide Studies and Prevention 5 (1):1-19.

Johnson, C. L. 2000. Perspectives on American kinship in the later 1990s. Journal of Marriage and Family 62 (3):623-639. 
Kaplan, M. A. 1998. Between dignity and despair: Jewish life in Nazi Germany. New York, NY: Oxford University Press.

- 2005. Jewish daily life in Germany. New York, NY: Oxford University Press.

Knowles, A. K., T. Cole, and A. Giordano eds. 2014. Geographies of the Holocaust.

Bloomington, IN: Indiana University Press.

Mariot, N., and C. Zalc. 2010. Face à la persécution: 991 Juifs dans la guerre (Facing persecution: 991 Jews in the war). Paris, France: Odile Jacob, Fondation pour la mémoire de la Shoah (Foundation for the memory of the Shoah).

-2017. Reconstructing trajectories of persecution: Reflections on a prosopography of Holocaust victims. In Microhistories of the Holocaust, eds. C. Zalc and T. Bruttmann, 85-112. New York, NY: Berghahn Books.

Ofer, D. 1999. Cohesion and rupture: The Jewish family in East European ghettos during the Holocaust. In Coping with Life and Death: Jewish Families in the Twentieth Century., Studies in Contemporary Jewry., ed. P. Y. Medding, 143-165. New York, NY: Oxford University Press.

Ofer, D., and L. J. Weitzman. 1999. Women in the Holocaust. New Haven, CT: Yale University Press.

Perosino, A. 2005. La Shoah in provincia di Alessandria (The Shoah in the province of Alessandria). Genoa, Italy: Le Mani.

Pimlott-Wilson, H., and S. M. Hall. 2017. Everyday experiences of economic change: Repositioning geographies of children, youth and families. Area 49 (3):258-265. 
Pine, L. 2000. German Jews and Nazi family policy. Holocaust Educational Trust research papers $1(6): 1-22$.

- 2004. Gender and the family. In The historiography of the Holocaust, ed. D. Stone, 364-382. Basingstoke, United Kingdom: Palgrave Macmillan.

Rösslør, M. 1989. Applied geography and area research in Nazi society; Central place theory and planning, 1933 to 1945. Environment and Planning D: Society and Space 7 (4):419-431.

Salmoni, G. 1998. Interview 40749. USC Shoah Foundation Visual History Archive. USC Shoah Foundation (last accessed 8 October 2019).

-2005. Coerenza e coraggio: Italiani in guerra (Consistency and courage: Italians at war). Genoa, Italy: Fratelli Frilli.

—2013. Una storia nella storia: Ricordi e riflessioni di un testimone di Fossoli e Buchenwald (A story in history: Memories and reflections of a witness from Fossoli and Buchenwald). Genoa, Italy: Fratelli Frilli.

_2016. Buchenwald: Una storia da scoprire (Buchenwald: A story to discover). Genoa, Italy: Fratelli Frilli.

Sarfatti, M. 2005. La Shoah in Italia: La Persecuzione degli ebrei sotto il fascismo (The Shoah in Italy: The persecution of Jews under fascism). Turin, Italy: Einaudi.

_2006. The Jews in Mussolini's Italy: From equality to persecution. Madison, WI: The University of Wisconsin Press. 
Scomazzon, F. 2005. “Maledetti figli di giuda, vi prenderemo!": La caccia nazifascista agli ebrei in una terra di confine: Varese, 1943-1945 ("Damn sons of judah, we will catch you! ": The Nazi-fascist hunt for Jews in a borderland: Varese, 1943-1945"). Varese, Italy: Arterigere.

Tarrant, A., and S. M. Hall. 2019. Everyday geographies of family: Feminist approaches and interdisciplinary conversations. Gender, Place \& Culture :1-11.

Terracina, P. 1998. Interview 41114. USC Shoah Foundation Visual History Archive. USC Shoah Foundation (last accessed 8 December 2019).

Valentine, G. 2008. The ties that bind: Towards geographies of intimacy. Geography Compass 2 (6):2097-2110.

Voigt, K. 1989. Zuflucht auf Widerruf: Exil in Italien, 1933-1945 (Refuge on withdrawal: Exile in Italy, 1933-1945). Stuttgart, Germany: Klett-Cotta.

Wardi, D. 1992. Memorial candles: Children of the Holocaust. London, United Kingdom: Tavistock.

Weitzman, L. J. 2017. Resistance in everyday life: Family strategies, role reversals, and role sharing in the Holocaust. In Jewish families in Europe, 1939-present: history, representation, and memory, ed. J. B. Michlic, 46-66. Lebanon, NH: Brandeis University Press.

Zuccotti, S. 1987. The Italians and the Holocaust: Persecution, rescue and survival. London, United Kingdom: Halban. 
MAËL LE NOC is a PhD candidate in Geography at Texas State University, San Marcos, TX 78666. E-mail: mael.1enoc@,txstate.edu. His research interests include geographical aspects of the Holocaust, interactions between space and persecution, and the issue of family separations in instances of genocide.

ALBERTO GIORDANO is a Professor of Geography at Texas State University, San Marcos, TX 78666, and the 2018-2019 President of UCGIS, the University Consortium for Geographic Information Science. E-mail: ag22@txstate.edu. He is a founding member of the Holocaust Geographies Collaborative, a network of researchers and scholars interested in bringing geographical approaches, methods, and perspectives to the study of the Holocaust and other genocides. He is also involved in projects related to spatial applications to forensic anthropology.

TIM COLE is a Professor of Social History and Director of the Brigstow Institute at the University of Bristol, Bristol BS8 1TH, United Kingdom. E-mail: tim.cole@,bristol.ac.uk. His research interests include Holocaust geographies and histories, environmental histories and coproduced research with communities and artists. 